\title{
Mariusz Wołos, O Pitsudskim, Dmowskim i zamachu majowym. Dyplomacja sowiecka wobec Polski w okresie kryzysu politycznego 1925-1926, Wydawnictwo Literackie, Kraków 2013, ss. 461
}

\section{(c) $\odot \ominus$}

DOI: http://dx.doi.org/10.12775/KLIO.2013.061

$\mathrm{N}$ akładem Wydawnictwa Literackiego w Krakowie ukazała się w 2013 roku książka Mariusza Wołosa pt. „O Piłsudskim, Dmowskim i zamachu majowym. Dyplomacja sowiecka wobec Polski w okresie kryzysu politycznego 1925-1926”. Wydawnictwo Literackie, obok Spółdzielni Wydawniczej „Czytelnik”, Instytutu Wydawniczego PAX czy Wydawnictwa Naukowego PWN, należy do najważniejszych i ogólnie poczytnych w Polsce. Zostało założone w 1953 roku i od 60 lat swojego istnienia publikuje prace najwybitniejszych polskich i światowych pisarzy, poetów, eseistów czy historyków. W tym miejscu wymieńmy tylko polskich autorów - w kolejności alfabetycznej - Henryka Batowskiego, Witolda Gombrowicza, Zbigniewa Herberta, Gustawa Herlinga-Grudzińskiego, Stanisława Lema czy Sławomira Mrożka. Redaktorem naczelnym Wydawnictwa Literackiego jest obecnie (2013) Małgorzata Nycz.

Mariusz Wołos, rocznik 1968, należy, obok Marka Kornata (1971) i Arkadiusza Adamczyka (1969), do młodego pokolenia profesorów historyków XX wieku wybijających się ponad przeciętność ze względu na jakość swoich publikacji, a także ich wartość dla polskiej historiografii. Do tej pory opublikował (tylko książki) m.in.: „Alfred Chłapowski (1874-1940). Biografia ambasadora Polski we Francji”, Toruń 1999; „Generał dywizji Bolesław Wieniawa-Długoszowski. Biografia wojskowa”, Toruń 2000; „Francja - ZSRR. Stosunki polityczne w latach 1924-1932”, Toruń 2004; „Treugol'nik: Moskva-Varšava-Berlin: očerki istorii sovetsko-pol'sko-germanskih otnošenij v 1918-1939 gg." (wspólnie z Julią Kantor), Sankt Petersburg 2011. Był też redaktorem wydawanych przez Polski Instytut Spraw Międzynarodowych „Polskich Dokumentów Dyplomatycznych za rok 1931”, Warszawa 2008. Oprócz tego jest autorem ponad 120 publikacji naukowych opublikowanych 
po polsku, rosyjsku, francusku, angielsku i włosku. Mariusz Wołos jest obecnie profesorem Uniwersytetu Pedagogicznego im. Komisji Edukacji Narodowej (nie Historycznej - sic!- czwarta strona okładki) w Krakowie i Instytutu Historii Polskiej Akademii Nauk w Warszawie. W latach 2007-2011 był dyrektorem Stacji Naukowej PAN w Moskwie i stałym przedstawicielem PAN przy Rosyjskiej Akademii Nauk. Prezentowana książka jest rezultatem jego wieloletnich kwerend w archiwach Federacji Rosyjskiej.

Książka Mariusza Wołosa wydana została niezwykle starannie. Wrażenie robi okładka w twardej oprawie, na której widnieje postać Józefa Piłsudskiego, z lekka pochylonego i zafrasowanego nad stołem, a raczej Polską, która przeżywała jeden z największych kryzysów dwudziestolecia międzywojennego. Wewnątrz, na dobrej jakości papierze, treść wydrukowano z odpowiednimi marginesami, interlinią i światłem pomiędzy literami. Dodatkowo w książce znajdziemy dwadzieścia osiem zdjęć bardzo dobrej jakości, adekwatnie dobranych i umieszczonych zgodnie z biegiem rozważań, bibliografię, wykaz skrótów, źródła ilustracji, indeks nazwisk, spis treści oraz przypisy - zazwyczaj umieszczane na dole strony, w tym wypadku znalazły się na końcu książki. W książce Wołosa to zupełnie nie razi, uważam nawet, że z tego powodu opracowanie znajdzie dodatkowych czytelników, którzy historią XX wieku, szczególnie jej pierwszą połową, interesują się wyłącznie amatorsko.

Zasadnicza część pracy podzielona została, z małymi wyjątkami, chronologicznie na siedem rozdziałów, wstęp oraz zakończenie. W rozdziale pierwszym Tto i antecedencje - wstępnym i wprowadzającym - autor scharakteryzował sowiecki aparat dyplomatyczny odpowiedzialny za kontakty z Polską, podając krótkie biogramy połpredów i innych przedstawicieli dyplomatycznych ZSRS w Warszawie, m.in.: Lwa Karachana, Leonida Obolenskiego, Piotra Wojkowa, Aleksandra Uljanowa czy Michaiła Arkadiewa.

Rozdział drugi, Próba powrotu na scenępolityczna "rycerza mętnej wody”, opisuje plany sowieckich decydentów wobec Rzeczypospolitej (sprawy wewnętrzne i zewnętrzne) oraz przedstawia punkt widzenia Moskwy na temat kryzysu politycznego nad Wisłą trwającego w połowie lat dwudziestych i możliwości powrotu Józefa Piłsudskiego - „rycerza mętnej wody” ${ }^{1}$ - do

${ }^{1}$ Piłsudski był określany przez sowieckich dyplomatów również jako: zastużony mar- 
czynnej polityki. W tej części pracy znajdziemy także odniesienia do sytuacji wewnętrznej we Francji czy w Wielkiej Brytanii. Należy w tym miejscu sprostować, że słynny „list Zinowiewa” był niezaprzeczalnie falsyfikatem (s. 359) $)^{2}$.

W rozdziale trzecim, Między Moskwa, Warszawa a Sulejówkiem: sonda$\dot{z} e$, kontakty, informacje, Wołos obrazuje nam metody pozyskiwania informacji, sposoby działania oraz kontakty sowieckiej placówki dyplomatycznej w Warszawie. Niezwykle intrygujące były ustalenia dotyczące powiązań m.in. Wojkowa z czołowymi przedstawicielami polskiej prawicy, nie wyłączając samego Romana Dmowskiego, nazywanego przez Sowietów „niekoronowanym królem endecji”.

W rozdziale czwartym, zatytułowanym Wokót wielkiej niewiadomej: czy $w$ Polsce będzie zamach stanu?, omówiona została sytuacja wewnętrzna w Polsce na kilkanaście tygodni (przełom lutego i marca 1926 r.) przed zamachem stanu. Autor przedstawia nam działania sowieckiej dyplomacji, która z dużym wyczuciem - w większości - przewidziała wydarzenia mające rozegrać się w stolicy, niemniej jednak termin zamachu wyraźnie zaskoczył połpredstwo (Wojkowa). Ten ostatni wielokrotnie też popełniał znaczące błędy w raportach do Ludowego Komisarza Spraw Zagranicznych w Moskwie (LKSZ). Dla przykładu, charakteryzując Juliusza Malczewskiego nowego ministra spraw wojskowych - uznał go za zwolennika Piłsudskiego, a był on przecież jego oponentem. Z tego ustępu książki uważny czytelnik zdobędzie jeszcze jedną istotną informację, a mianowicie o czujności i krytycznym podejściu do otrzymywanych wiadomości przez pracowników LKSZ, choćby Borisa Stomoniakowa (s. 155), który ganił swojego podwładnego i nakazywał mu „wziąć się za lepsze pozyskiwanie informacji w Warszawie" (s. 162).

Rozdział piąty, Demonstracja przeksztatcona w przewrót, opisuje przebieg zamachu z perspektywy sowieckich dyplomatów akredytowanych w Warszawie, Berlinie i Moskwie. Z tej części pracy dowiadujemy się o ich

szatek, rycerz bez strachu i skazy, wspótczesny Zagtoba, polski Kierenski czy maty Napoleon o wojenno-awanturniczych sktonnościach (passim).

2 L. Chester, S. Fay, H. Young, The Zinoviev Letter, London 1967. 
reakcjach i opiniach na temat nowej władzy w Polsce, mniej znanej niż narodowa demokracja. Mimo że Wołos wspomina, że endecy nie afiszowali się znajomością i kontaktami z sowieckimi dyplomatami, brakuje tu informacji o tym, jak Piłsudski zapatrywał się na znajomości (dobre stosunki), o których z pewnością musiał wiedzieć.

W rozdziale szóstym, Umacnianie wtadzy, autor przedstawił proces przejmowania kontroli w państwie przez Marszałka. Czytając ten fragment książki, poznajemy sposoby pozyskiwania informacji przez połpredstwo w Warszawie. I tu, jak zresztą w całej książce, Wołos wspiera się przetłumaczonymi przez siebie cytatami pochodzącymi z korespondencji dyplomatycznej. Dla przykładu Wojkow do Stomoniakowa:

W grupie Lewiatana szczególne znaczenia mają akurat te osoby, które pozostają
osobiście ze mną w wyjątkowo dobrych stosunkach i które, z jednej strony, są nam
bliskie jak członkowie Polsko-Sowieckiej Izby Handlowej [...], z drugiej strony, są
bliscy nam ze względu na swoją orientację, jak na przykład Andrzej Wierzbicki,
książę [Stanisław] Lubomirski i inni. Wszystko to są ludzie, z którymi niemało
wypiłem, niemało zjadłem obiadów i jestem dobrze zaznajomiony [podkreślenie
- K.K.]. Między innymi z Andrzejem Wierzbickim mam szczególnie dobre sto-
sunki osobistej przyjaźni, co może odegrać w przyszłości swoją rolę. Szczególnie
interesującą sprawą jest to, że być może przy pomocy tegoż Wierzbickiego i innych
zdołamy zyskać większy wpływ na Ministerstwo Spraw Zagranicznych w obecnym
składzie niż na [niegdysiejsze] ministerstwo Skrzyńskiego (s. 243).

W ostatnim, siódmym rozdziale zatytułowanym Od kryzysu gabinetowego do stabilizacji: utworzenie rzadu Józefa Pitsudskiego i pierwsze miesiące jego dziatalności, autor omówił sowiecki punkt widzenia na sytuację wewnętrzną i politykę zagraniczną Polski w ostatnich miesiącach 1926 roku. Ponadto udało się Wołosowi przedstawić aktywność LKSZ wobec Polski na arenie międzynarodowej, ze szczególnym uwzględnieniem bilateralnych stosunków na linii Warszawa-Kowno.

Jak już pisałem wyżej, książka Mariusza Wołosa wydana została z najwyższą pieczołowitością, z dbałością o najmniejsze detale. Próżno szukać w niej jakiś lapsusów językowych, literówek, nie mówiąc już o błędach merytorycznych. W trakcie uważnego czytania dzieła zwróciła uwagę jedynie jedna kwestia związana z rozwinięciem terminu limitrofy, który powinien 
być wyjaśniony za pierwszym razem (s. 91), a został podany w dalszej części tekstu (s. 193). W recenzowanej książce zwraca uwagę język redagowanych przez Sowietów raportów. Wydaje się, że na przestrzeni wielu lat nie uległ on zmianie ${ }^{3}$. Różni się on zdecydowanie od raportów polskich dyplomatów akredytowanych przy Dworze św. Jakuba ${ }^{4}$. Z lektury wynika także, że do Warszawy trafiali połpredzi drugiej lub trzeciej klasy. Nie mogli się oni równać np. ze Stomoniakowem, zastępcą szefa sowieckiej dyplomacji, który po stokroć przewyższał ich swoją wiedzą, umiejętnościami oraz tzw. zmysłem analitycznym i możliwościami dedukcyjnymi. Zastanawiające jest dlaczego - i nie jest to do końca wyjaśnione - „Wojkow i jego pracownicy nie zmienili sposobów działania” (s. 290). Dająca do myślenia była również polityka Moskwy - dlaczego go po prostu nie odwołano? Z drugiej strony zgodzić wypada się z autorem, że

Wojkow był poniekąd złem koniecznym. Z tego, że do Warszawy oddelegowano osoby, które trudno określić mianem wytrawnych dyplomatów, wolno wyciągnąć wniosek potwierdzający tezę o drugorzędnej roli Rzeczypospolitej w polityce zagranicznej ZSRS w interesującym nas okresie (s. 345).

Czy jednak w takim przypadku reakcje Stomoniakowa wobec Wojkowa byłyby takie ostre i poniżające? Kończąc część krytyczną recenzowanej pracy, zastanawiam się także nad istotną rolą sowieckiej komórki berlińskiej, wszak Wołos przy większości informacji pochodzących z Oddziału Informacji Dyplomatycznej LKSZ w Berlinie nie mógł z całą pewnością podać źródła ich pochodzenia, słusznie asekurując się słowami: „prawdopodobnie”, „niewykluczone” etc. (zob. np. s. 299). Długoletnia kwerenda w archiwach moskiewskich (m.in. Archiwum Polityki Zagranicznej Federacji Rosyjskiej i Rosyjskim Państwowym Archiwum Historii Społeczno-Politycznej), do których dostęp był i jest nadal niezwykle utrudniony dla badaczy zagranicznych, przyniosła $\mathrm{w}$ tym przypadku znakomite efekty.

3 Por. J. Borzęcki, Pokój ryski 1921 roku i ksztattowanie się międzywojennej Europy Wschodniej, Warszawa 2012.

${ }^{4}$ Zob. K. Kania, Wielka Brytania 1918-1939 w świetle polskich źródet dyplomatycznych, Toruń 2007. 
Otrzymaliśmy niezwykle interesującą pracę opisującą sprawy zupełnie nieznane w polskiej historiografii ${ }^{5}$. Lekkie pióro Wołosa sprawia, że książkę czyta się jak najlepszą powieść i trudno nie zgodzić się z zamieszczonymi na tylnej okładce rekomendacjami zachęcającymi do jej przeczytania. Dodałbym tylko, że jest to obowiązkowa lektura dla każdego, kto interesuje się historią Polski i Związku Sowieckiego.

\section{Krzysztof Kania (Toruń)}

5 Interesujący zbiór dokumentów Przewrót majowy 1926 roku w oczach Kremla, Warszawa 2009 opracowany przez B. Musiała przy współpracy J. Szumskiego zawierał materiały pochodzące przede wszystkim z fondu Feliksa Dzierżyńskiego przechowywanego w Rosyjskim Państwowym Archiwum Historii Społeczno-Politycznej w Moskwie. 